(unrevised) leaflet had implied that homosexuals with stable partnerships were still eligible as donors. Certainly, our homosexual donors had a much lower incidence of markers for sexually transmitted disease than those attending special clinics, where half were reported to have antihepatitis $B$ core antigen. ${ }^{3}$ This should not encourage complacency, however, as HTLV-III has been isolated from the lymphocytes of some at risk people who were negative for anti-HTLVIII. ${ }^{5}$ We intend to follow up these homosexual donors.

It is alarming that some male homosexuals still donate blood, and it is vital that all possible measures are taken to discourage this.

We thank Dr Jane Caseley, Dr R Zelisko, and all donors and staff at the Margaret Street Clinic, London; and staff in the virology section of the department of microbiology, the joint Middlesex Hospital and University College Medical Schools, for providing the hepatitis B and HTLV-III serology.

1 Anonymous. Prevention of acquired immune deficiency syndrome (AIDS): report of inter agency recommendations. $M M W R \quad 1983 ; 32: 101-3$.

2 Curran JW, Lawrence DN, Jaffe $\mathrm{H}$, et al. Acquired immunodeficiency syndrome (AIDS) associated with transfusion. $N$ Engl $\mathcal{F}$ Med 1984;310:69-75

Tedder RS, Cameron CH, Wilson-Croome R, Howell DR, Colgrove A, Barbara JAJ. Contrasting patterns and frequency of antibodies to the surface, core and in homrence f Med Virol 1980;6:323-32

4 Cheingsong-Popov $G$, Weiss RA, Dalgleish $A$, et al. Prevalence of antibody to human T-lymphotropic virus type III in AIDS and AIDS-risk patients in human Tymphotropic virus

5 Salahuddin SZ, Groopman JE, Markham PD, et al. HTLV-III in symptom-free seronegative persons. Lancet 1984 ;ii:1418-20.

(Accepted 1 February 1985)

North London Blood Transfusion Centre, Edgware, Middlesex HA8 9BD

MARCELA CONTRERAS, BSC, MD, director

PATRICIA E HEWITT, MRCP, MRCPATH, deputy director

JOHN A J BARBARA, MSC, PHD, top grade microbiologist

PETER Z MOCHNATY, BSC, scientific officer

Correspondence to: Dr Marcela Contreras.

\section{Ultrasound in first trimester shows no difference in fetal size between the sexes}

At birth girls are on average smaller than boys in both length and weight, differences in weight ranging from 50 to $150 \mathrm{~g}$ and in length ranging from 0.5 to $1.0 \mathrm{~cm} .^{1} \mathrm{It}$ is well documented that these differences are not present until after the 20th week of gestation. ${ }^{12}$ There has been recent controversy on how early in pregnancy these differences can be detected by ultrasonic anthropometry. Pedersen reported that boy fetuses were on average larger than girl fetuses as early as 8-12 weeks as calculated by menstrual age, thus suggesting that this early divergence in size was due to a genetic rather than hormonal influence. ${ }^{3}$ Our data, however, show no statistically significant difference in size between boy and girl fetuses during this early stage of pregnancy.

\section{Subjects, methods, and results}

Fetal size was evaluated by both crown-rump length and biparietal diameter using ultrasound measurement (Searle Imager 2300, dynamic scanner). A total of 1208 healthy pregnant women were examined. All fetuses underwent measurement of crown-rump length up to 14 weeks of gestation (as measured from date of last menstrual period) and 666 also had the biparietal diameter measured up to 22 weeks. In addition, data were collected from 22 pregnancies conceived by artificial insemination using donor semen.

Crown-rump length-A total of 1208 consecutive subjects with normal pregnancies were evaluated in the screening programme measuring crownrump length. Eighty per cent of all pregnant women in the Linköping area are examined before the 15 th gestational week. To study a possible difference in measurements accurately, we included only those pregnancies in which the absolute difference in ages calculated from last menstrual period and crown-rump length ${ }^{4}$ was less than eight days. If crown-rump lengths differ according to fetal sex, as suggested, ${ }^{3}$ girl fetuses would in general have a shorter menstrual age calculated from crown-rump length than that calculated from last menstrual period compared with boys. This would be readily observed in a $\chi^{2}$ analysis of the distribution of observed and expected numbers of fetuses classified according to the difference in days between dates calculated by the two methods. ${ }^{4}$ The results (table) showed no significant difference in distribution of crown-rump lengths between male and female fetuses as judged from the differences in dating between menstrual age and age estimated from crown-rump length $\left(p=0.38\right.$ according to $\chi^{2}$ analysis and mode $=0$ days of difference for both groups). Data from 22 pregnancies with dates calculated from both time of insemination and crown-rump length ${ }^{5}$ (13 male, nine female fetuses) showed no statistically significant difference in median values using the Mann-Whitney $U$ test.

Biparietal diameter-Altogether 666 apparently normal pregnancies dated by crown-rump length were further investigated by measurement of biparietal diameter between the 11 th and 22 nd weeks. Analysis by $\chi^{2}$ test showed no statistically significant difference in diameters between male and female fetuses as judged from observed and expected sizes according to menstrual age.

Observed $(O)$ and expected $(E)$ numbers of fetuses classified according to difference in age as calculated frcm date of last menstrual period and crown-rump length

\begin{tabular}{|c|c|c|c|c|c|c|}
\hline \multirow{2}{*}{$\begin{array}{l}\text { Difference in days } \\
\text { between menstrual age } \\
\text { and age estimated from } \\
\text { crown-rump length }\end{array}$} & \multicolumn{3}{|c|}{ Girl fetuses } & \multicolumn{3}{|c|}{ Boy fetuses } \\
\hline & 0 & $\mathrm{E}$ & $x^{2}$ & O & $\mathrm{E}$ & $x^{2}$ \\
\hline $\begin{array}{l}-7 \\
-6 \\
-5 \\
-4 \\
-3 \\
-2 \\
-1 \\
0 \quad \text { (mode) } \\
1 \\
2 \\
3 \\
4 \\
5 \\
6 \\
7\end{array}$ & $\begin{array}{r}21 \\
31 \\
30 \\
39 \\
57 \\
39 \\
64 \\
66 \\
45 \\
47 \\
37 \\
18 \\
8 \\
9 \\
7\end{array}$ & $\begin{array}{r}18 \cdot 7 \\
25 \cdot 2 \\
37 \cdot 3 \\
39 \cdot 2 \\
48 \cdot 5 \\
46 \cdot 2 \\
62 \cdot 1 \\
69 \cdot 1 \\
51 \cdot 3 \\
49 \cdot 9 \\
28 \cdot 9 \\
19 \cdot 6 \\
8 \cdot 4 \\
7 \cdot 5 \\
6 \cdot 1\end{array}$ & $\begin{array}{l}0 \cdot 2 \\
1 \cdot 1 \\
1 \cdot 3 \\
0 \cdot 0 \\
1 \cdot 3 \\
1.0 \\
0 \cdot 0 \\
0 \cdot 1 \\
0 \cdot 7 \\
0 \cdot 1 \\
2 \cdot 0 \\
0 \cdot 1 \\
0 \cdot 0 \\
0 \cdot 1 \\
0 \cdot 0\end{array}$ & $\begin{array}{l}19 \\
23 \\
50 \\
45 \\
47 \\
60 \\
69 \\
82 \\
65 \\
60 \\
25 \\
24 \\
10 \\
7 \\
6\end{array}$ & $\begin{aligned} 21 \cdot 3 \\
28 \cdot 8 \\
42 \cdot 7 \\
44 \cdot 8 \\
55 \cdot 5 \\
52 \cdot 8 \\
70 \cdot 9 \\
78 \cdot 9 \\
58 \cdot 7 \\
57 \cdot 1 \\
33 \cdot 1 \\
22 \cdot 4 \\
9 \cdot 6 \\
8.5 \\
6.9\end{aligned}$ & $\begin{array}{l}0.2 \\
1.0 \\
1.1 \\
0.0 \\
1.1 \\
0.9 \\
0.0 \\
0.1 \\
0.6 \\
0.1 \\
1.7 \\
0.1 \\
0.0 \\
0.1 \\
0.0\end{array}$ \\
\hline
\end{tabular}

Sum of $\chi^{2}=14 \cdot 9 ; \mathrm{df}=14 ; \mathrm{p}=0 \cdot 38$

\section{Comment}

In this series data based on measurements of crown-rump length and biparietal diameter showed no evidence of a difference in size between boy and girl fetuses as early as the eighth to 22 nd weeks of gestation. This finding, validated by three sets of data-namely, crown-rump length measured six to 14 weeks after the date of the last menstrual period, biparietal diameter measured at 11-22 weeks, and measurements in pregnancies conceived by artificial insemination of donor semen-contradicts the report that a difference in size due to fetal sex occurs in the first trimester. ${ }^{3}$

1 Thomson AM, Billewicz WZ, Hytten FE. The assessment of fetal growth fournal of Obstetrics and Gynaecology of the British Commonwealth 1968;75:903-16. Persson P-H, Grennert L, Gennser G. Impact of fetal and maternal factors on the normal growth of the biparietal diameter. Acta Obstet Gynecol Scand 1978 78:21-7.

3 Pedersen JF. Ultrasound evidence of sexual difference in fetal size in first trimester Br Med F 1980;281:1253.

4 Robinson HP, Fleming JEE. A critical evaluation of sonar "crown-rump length" Selbing A, Fiällbrant B. Accuracy of conceptual age estimation from fetal crownrump length. $7 C U$ 1984;12:343-6.

(Accepted 4 December 1984)

Ultrasound Laboratory, Department of Obstetrics and Gynaecology,

Linköping University Hospital, S-581 85 Linköping, Sweden

ANDERS SELBING, MD

School of Medicine, University of Kansas, Kansas City, USA

KIMBERLY MCKAY, MS, honorary Fulbright scholar

Correspondence and requests for reprints to: Dr Anders Selbing. 